\title{
Implementation of Permaculture Design to Achieve Food Self- Sufficiency in Mood Forest Farm, Hualien County, Eastern Taiwan
}

\author{
Elok Sukmarani ${ }^{1}$, Jiehn-Fu Tsai ${ }^{2}$ \\ ${ }^{1}$ National Dong Hwa University, Taiwan \\ 2 National Dong Hwa University, Taiwan
}

\begin{abstract}
The Covid-19 pandemic is a global health crisis that has hit more than 100 countries including Taiwan. The agricultural sector is one of the sectors that has experienced the impact of the Covid-19 pandemic. One of the strategies and efforts that can solve it is food self-sufficiency through increasing production, diversifying local food, and developing sustainable agriculture. While in the process to achieve food self-sufficiency, there are also many challenges like intensive farming. Therefore, an effort is needed to improve the environment, the quality, and the safety of agriculture products through ecological balance. Permaculture is the system that uses natural principles between humans to live more productive with their environment. Through this concept, practitioners can be more productive with their environment. The study aims to analyze the implementation of permaculture design for food self-sufficiency on farm in eastern Taiwan. This study was used qualitative methods through interviews, participant observation, field notes, documentation to collect data. The result that practitioners integrate several designs based on principles and ethics of permaculture, including providing their food, fruit, vegetables, and livestock products. Practitioners also integrate elements into a multi-functional design, creative ideas to solve the problem that they face and make these efforts a challenge for them, such as bird kites and eagle poles for rice paddy pest problems. Thus, the concept of permaculture has been proven to increase productivity, harmony, and sustainability with the environment through the use of natural principles and human life.
\end{abstract}

\section{CONTACT}

elok.sukmarani@gmail.com

\section{KEYWORDS}

Environment, Food Security, Permaculture

\section{INTRODUCTION}

The Covid-19 (coronavirus disease of 2019) pandemic is a global health crisis. The COVID-19 is an infectious disease caused by Severe Acute Respiratory Syndrome Coronavirus 2 (SARS-CoV-2) [1]. The virus has affected the lives of many people in the world. Wuhan, the capital of China's Hubei province, was the location of the first detected cases of this coronavirus outbreak. At present, this pandemic hit more than 100 countries, specifically 220 countries, and territories, including Taiwan. As of May 29, 2021, a total of 169,118,995 confirmed cases with $3,519,175$ deaths globally were reported by WHO [2]. All countries affected by Covid-19 are facing a difficult time overcoming the outbreak. The agricultural sector is one of the sectors that has experienced the impact of the Covid-19 pandemic. For example, limited distribution, reduced workforce, increased prices for certain commodities, and disruption of supply chains. Food security is being threatened as a result of this pandemic because it affects the supply and demand for food in society [3]. One of the strategies and efforts that can solve it is create plant diversity, design cropping patterns, optimize land, and design multifunctionality systems on the farm with the aim of practitioners being able to produce and harvest their own plants as their food supply.

Currently, permaculture is a design that is a good concept in agricultural sector. A harmonious system to integrate of landscape and people providing their food, energy, shelter, and other material and non-material needs in a sustainable way [4]. Permaculture applies a more holistic design to both farming crops and animal stock which have multifunctional to each other. For instance, the practitioners are designing food forest in ther land with the function to harvest a lot product of them such as fruit, vegetable, and animal product in one area system. For instance, the practitioners are designing food forests in their land with the function to harvest a lot of products of them such as fruit, vegetable, herbs, and other product. Besides it, permaculture has ethics and principles ecologically as a basic to implemented in surrounding us. Recently, permaculture practice has actually been spread rapidly internationally and many countries have adopted this concept [5]. Taiwan has not been able to achieve food self-sufficiency according to the country's target. Especially, with the impact of the pandemic that is currently attacking the local population of this country. While in the process to achieve food self-sufficiency, there are also 
many challenges. Intensive farming in this country is still high, such as the use of agricultural chemicals to achieve maximum production. Although Intensive farming practices can achieve maximum productivity, they also can have a negative impact on both human health and natural ecosystems. The farmers use highly intensive inputs and energy to achieve it, such as the use of chemical pesticides and fertilizer [6]. Therefore, an effort is needed to improve the environment, the quality, and the safety of agriculture products through ecological balance. Through the concept of permaculture, practitioners can be more productive with their environment and able to provide their food in ecology and sustainable way, without damage nature surrounding them. The practitioners concern food safety of their families through the use of organic material in their farming system. They can make problems to solutions such as rotated plants to improve the soil to make it healthier and fertile, also integrating ecological ponds around the rice fields that have multifunctions to each other.

Eastern Taiwan includes two counties, Hualien and Taitung. Eastern Taiwan has many natural resources, agricultural culture, and diverse local communities. This wealth is a great opportunity for farmers, especially permaculture practitioners in this area. The study aims to analyze the implementation of permaculture design for food self-sufficiency on farm in eastern Taiwan. One example of its implementation is carried out by a family who is a permaculture practitioner on their land called Mood Forest (牧于森林) farm, in Hualien County.

\section{METHODS}

This study was used a qualitative method with a case study approach. This study is located in one of the permaculture farms, namely Mood Forest in Pinghe Village, Shoufeng Townships, Hualien County, Eastern Taiwan. The study was used qualitative methods through interviews and participant observation, field notes, and documentation to collect data. Interviews were conducted directly with two people as permaculture practitioners on this farm. They are Hsu (Taiwanese, male, farmer) and Alinggo (Taiwanese, female, half-farmer/X-farmer, teacher) with unique and different backgrounds. Because the interview was also conducted in the participant observation activity, this interview has matched the reality on-site. In addition, the data is also supported by my field note and documentation. Participant observation is a way to collect data in naturalistic settings by who observe the common and uncommon activities of people being studied [7]. In this data collection session, we were involved in several activities on the farm location. The results of data collection through interviews, participant observations, field notes, and documentation were analyzed and obtained three main themes. There are permaculture concepts, achieve food self-sufficiency, also problem and challenge faced. Specifically, the result of the study is explained in the next section.

\section{RESULTS AND DISCUSSIONS}

Based on the data result with various methods described in the previous session, we interpret them, then compare them with several previous studies and related literature. There are three main results with their discussion as described below.

\section{Permaculture Concept}

Based on the results of interviews that have been conducted with key person (Hsu) that permaculture is one of the ways farming in agriculture. He is who has been a permaculture practitioner since 2014 in his farm, said:

"Permaculture just way to achieve natural farming"

"Natural farming is an idea in agriculture"

The concept of permaculture that she and her family integrate into this land is the right choice and decision for their family life. Alinggo feels happy about her family's decision. The practitioners have various designs of permaculture implementation. The practitioners have crop patterns design based on microclimatology. Also, they have ecology ponds with a lot of fish, water plants, and other elements. Other designs are pest control design, herbs garden, chicken shelter with a fruit tree on this land. The location of the land has a beautiful view, then Alinggo said when she first found out about this area because under Liyu mountain and has a lot of natural resources.

"Wow bere is beautiful. If I could, I hope I can have land in here"

with the feeling of being happy to have owned this land and managed it together with her family, they proved it through changes in this area. They developed a small land that had nothing to a large area with various elements that they currently have present. At present, their land area is around 3000 ping (9917.3 square meters). Moreover, 
they also prove it by getting several certificates for their land, such as certificates for eco-friendly farming and organic farming. Environmentally-friendly farming certificates are proof of their land joining with a nongovernment association in Hualien related to the field of permaculture and environmentally friendly farming. This purpose of the association is one of the mission's government that related the policies to realize environmentallyfriendly agriculture. While organic certificates, they got in 2016 and 2018.

However, their journey while managing the land for many years, they do not know about PDC or Permaculture Design Course. Alinggo said:

"PDC? I am not sure talk about this"

This activity is an important activity that is usually followed by practitioners to learn permaculture both for beginners or expert people. They will get a certificate after taking this course. The activities are usually carried out such as attending seminars but also practice on the field. Alinggo family is only active in participating in the activities of permaculture associations or environmentally friendly and organic agriculture. For example, presentations related to their land if there is a visit event, permaculture volunteer activities, and sometimes participating in other members' farms.

Uniquely, Hsu has a background in the journalist field on previous his job, he never had any experience in agriculture before, it did not make him hesitate in pursuing agriculture for these 7 years. At present, he has the ability to make bake, as a saxophonist, be a runner, and a farmer, especially a permaculture practitioner. In the beginning, He learned from reading various books and websites, attending agricultural seminars, experimenting, researching by himself, and various experiences from the important person who expert in the agriculture sector. Unlike Alinggo, whose background has in the agricultural sector. Alinggo had agriculture experiences because of her childhood with her family in the agriculture field. Alinggo said with her enthusiastic expression:

"He didn't have a childhood like me. But he learned it. He used a website, just like to bake"

"He learned how to bake, learned how to be a farmer, how to be a saxophone player"

In addition, when they face a problem in their land, they never give up on solving it and try to make various designs as a challenge for them such as choose the kind of plant, new pest management, and other designs. They adopt the mindset of continuing to try when they fail to do something on their soil, as Hsu said that:

"Mistake and try it again" and Alinggo also said that:

"If we applying permaculture design, we must work with seriousness and patience because we are working with nature, and we hope that nature will do well and can cooperate with us"

Therefore, they never give up on their land, always try and learn. Not only do they both play a role in managing the land, but the involvement of their children is also very helpful and proves that their togetherness can make the family very harmonious and happy. Their children have drawing, read a book, and photographer hobbies. It no wonders, if this family has a principle is the learning through art for their permaculture farm.

\section{Achieve Food Self-Sufficiency}

By the integration of permaculture, Hsu can design various cropping patterns based on the microclimate, soil type, plant kind, and other functions. Then, his family can get a lot of benefits from every design function that he integrates and implements on his land. For example, his food forest design. He integrated several fruit trees such as guava, lemon, passion fruit, herb plants, ginger, and raising hen chicken, also rabbit in one area (Figure 1). Through the various functions of elements in one area, they can harvest fruit in a long or short period of time, and they can harvest eggs from their hens every month.

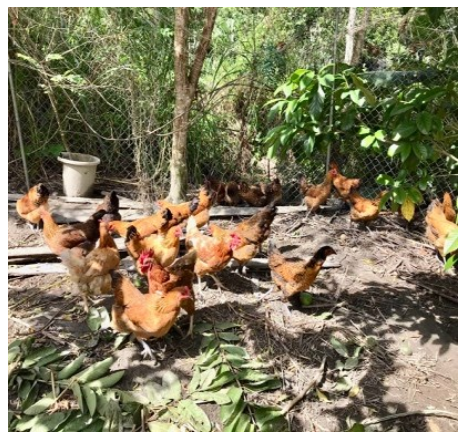

a

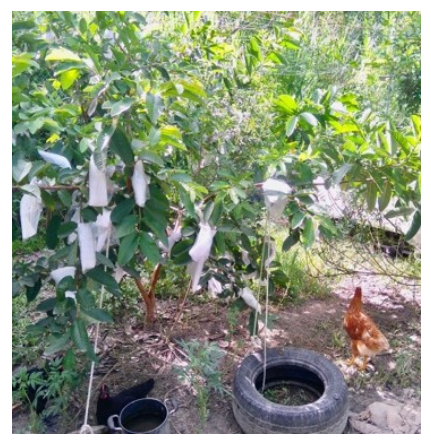

$\mathrm{b}$

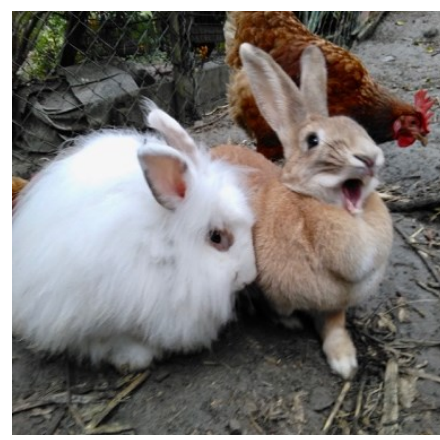

c

Figure 1. a) Chicken and guava trees; b) Chicken and lemon trees and c) Rabbit and chicken (Source: Mood Forest documentation) 
These elements also support to each other. For example, chicken manure in this area is a source an organic fertilizer for the plants to grow and develop very well. Also, the existing fruit trees are a shelter for the life of chickens, and the chickens often sleeping on the branches of the tree. Based on my observation and data analysis that the fruit tree's existence not only works for chickens but also for the life of rabbits and the small plants underneath. The fallen dry leaves also of course also function as organic matter to fertilize the surrounding soil. According to Alinggo (Hsu wife), they have many reasons for every element of their design. She said:

"I grow some types of ginger in under greenhouse and I also plant passion fruit on the top greenhouse with the function to reduce the sunlight".

it correlates with literature which statemented that in Sub-tropical regions, ginger is often interplant in agroforestry systems, because ginger is moderately tolerant of shade is well adapted to agroforestry systems [8].

Even when they harvest fruit or vegetables, they always share them with friends, neighbors, or visitors who come. This is because they often feel self-sufficient and share their land products as a form of caring for others. Their actions are one of permaculture ethics implementation, namely care of people because they care to each other, itself, community, and society. They have also applied other ethics such as caring for the earth such as not produce waste, and even utilizing natural resources in balanced and sustainable principles [4], [9].

In addition, their paddy fields are an important element in this land because it has economic value for their lives. Every harvest time, they always have customers who will order the rice, even though some of them are sold but they can still set some of their harvests to provide food for their own families. They have a rice planting season twice a year, specifically in wintertime and summertime. The practitioners have a rule for rice customers. The rice customers must commit order their rice three months before harvest. Alinggo and Hsu provide a social media group such as LINE and a Facebook page related to information on products from their land, especially rice yields. They manage their rice fields independently, although sometimes they use rice plowing field machines, they still go to the field to manage it. Alingo said:

"Even we used the machine on the big land, we still need to have some opportunity to do something like this (use by hand) because the big machine only can go in a straight line and still have this space"

The practitioner (Hsu) manages the rice paddy field from land management, soil and plant nutrients management, harvest till post-harvest management with his family. Uniquely, their packaging of rice products has the name of the farm and drawings their daughter made. It is also for other products, such as rosella jam.

In these two years, they have only one period of planting rice once. However, they can produce abundant yields, even more than before when they planted rice paddy twice per year. They prefer to rest their land by planting soybeans to improve soil nutrition. When the next planting period, their land will produce better and more abundant rice production than before. Moreover, the yield of this soybean crop is also for the availability of vegetables for their food. This management correlated with the literature regarding the role of soybean plants. The soybean is one of the legumes plants whose roots can reserves nutrients through a nitrogen fixation process by rhizobacteria. So, they can provide nitrogen nutrients to make fertile soils and then affect paddy plants in the next planting period [10]. The practitioners wish to get high yields in the next period through concern to make their fertility soil first. Based on consideration in every decision in land management here, they are never worried about the lack of stock of rice, vegetables, even fruit or eggs from their livestock as a food supply for this family and they are even able to provide their own food or independently. This condition is helpful when they faced the impact of the COVID-19 pandemic, especially through the integration of permaculture design on their land

\section{Problem and Challenges Faced}

In mood forest farm, the main problem is pests on the rice paddy fields. Based on the interview result, the pests attack their rice paddy is a small bird. Their rice paddy fields are the main target of little birds may be because of the strategic location of their land. Result of our observations, it obvious that there were no paddy fields like Mood Forest field. There are only vegetable and fruit farm, annual plant, reservoirs, wild grasses, and empty land surrounding Mood Forest location. Therefore, it is not wondrous that little birds like come to eat paddy grains. Supported by Hsu's statements that the grains of rice paddy were damaged and even empty of being eaten by little birds. We tried to identify this little bird in question. Based on its anatomical features, this bird is a sparrow (Passer spp.) which includes the Family Ploceidae. This bird is regular pests of ripening grain crops, especially rice paddy [11]. Hsu used natural enemies or predators of this bird and other creative designs to control the pest here. Recently, Hsu and his family designed a tool for controlling this bird. The use of giant bird kites is one of the creative ideas for controlling rice pests since the last 5 months by practitioners here (Figure 1a). They put up 3 strong bamboo poles in the edges of the field and each bamboo was connected with a rope which functions as a 
place for the kites to move when pushed by the wind movement. This design is a simulation of the presence of large birds upcoming and circling paddy fields that can become enemies for birds to prevent them from coming. They also implemented other creative solutions, it as bamboo high poles for eagle place in the middle of their rice fields (Figure 1b).

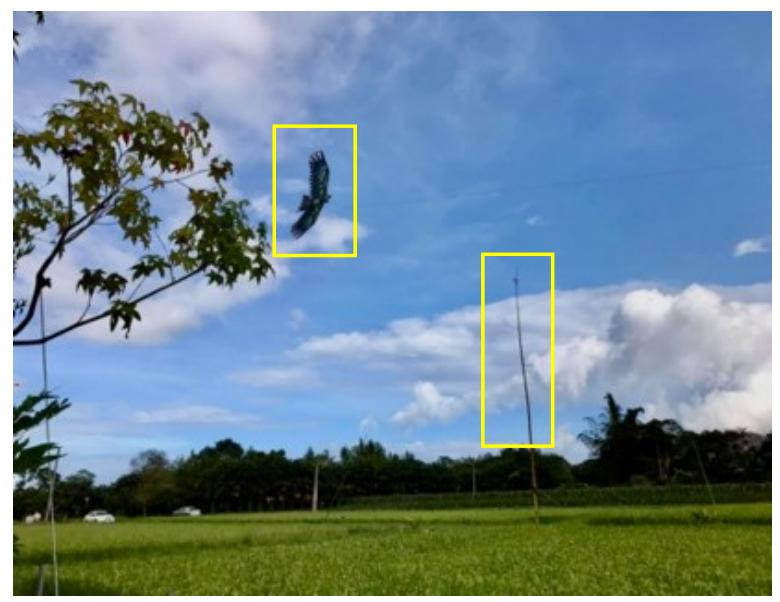

Figure 2. The Giant Bird Kite and Eagle Bamboo Pole

A pole made of bamboo with a very tall size was deliberately placed in the middle of the paddy field as a place for the eagle to stop. It is known that the eagle is one of the natural enemies of these birds which often become a pest of Mood Forest rice paddy field. One of the most famous predators in the bird world is the eagle [11].

Alinggo also explained that they not only used the eagle stand and bird kites faced the little bird. They also used the mechanic method for pest management, which is the use of firecrackers (figure 2).

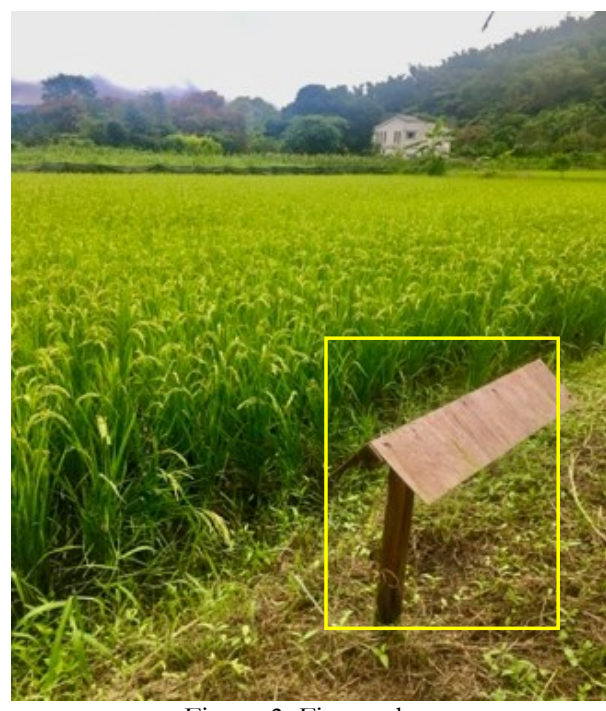

Figure 3. Firecracker

However, they won't use this tool every time because it costs a lot of money to buy new firecrackers. They will set on firecrackers when the birds come on a large scale, such as more than 15 birds. But, after a few minutes burned the firecrackers, the birds come back to the fields. Therefore, it is still a challenge for them to control bird pests. Moreover, the problem and challenges faced by practitioners depend on the character and condition of the land. Relate to previous research that practitioners in permaculture must understand the available elements in detail surrounding them that they can find and decide which design patterns are appropriate to land conditions [12]. The location of Mood Forest in the countryside and under the mountain specifically, but they were can to optimize the land with various permaculture designs without damaging nature surrounding them. Conversely, the problem and challenges face practitioners in the urban area is different, such as the limitation area of farming. But through permaculture design, practitioners might use their rooftop, yard or create the design on a small scale. Thus, they 
can still be productive and harvest from the elements they have. Then, they also get harvest products as a food supply for their own and their families.

\section{CONCLUSIONS}

The concept of permaculture has been proven to increase productivity, harmony in human life with their nature, and sustainability of the environment through using natural principles in an ecological way. Furthermore, this concept is one of the best ways to be food self-sufficient in the Covid-19 pandemic situation through integrated several designs on the land. The practitioner family always tries to make optimum use of their yard and land. Especially, those elements that have economic value as a result of food that can support their daily lives as food supply and also create income for them through rice sales for customers. In addition, they also have created income from other product sales such as chicken eggs, processed foods, herb products, and many other products. Besides rice paddy, they have crops that include various beans, chili, lettuce, banana, guava, papaya, lemon, passion fruit, pineapple, loquat, also other fruits and vegetables. For livestock in mood forest including poultry such as various chicken types and some geese and fish in their pond. At the beginning of getting this land, practitioners explained an emotional journey until finally now they get what they want easily on their land, without having to buy it in the market, except for other products that they do not have. Even though they buy products in the market, they still prioritize organic products even at expensive prices because their mindset is based on permaculture principles and ethics.

\section{ACKNOWLEGDEMENTS}

We gratefully acknowledge support from Mood Forest Farm, especially Alinggo Family as the study area, and another participant who help us while conducted this study.

\section{REFERENCES}

[1] World Health Organization Novel Coronavirus (2019-nCoV). Available online: https://covid19.who.int. Accessed on 30 May 2021.

[2] Lai, C.-C., Shih, T.-P., W.-C. Ko, Tang, H.-J., and Hsueh, P.-R. Severe acute respiratory syndrome coronavirus 2 (SARS-CoV-2) and coronavirus disease-2019 (COVID-19): The epidemic and the challenges. International Journal of Antimicrobial Agents 2020; 5: 1-9.

[3] Siche, R. What is the impact of COVID-19 disease on agriculture? 2020; 11:3-6.

[4] Mollison, B. Permaculture: a designer's manual. Tasmania: Tagari Publications. 1988.

[5] Ferguson, R.S., and Lovell, S.T. Permaculture for agroecology: design, movement, practice, and worldview. A review. Agron. Sustain. Dev 2014; 34: 251-274.

[6] Someus, E. Recycling and upgrading of bone meal for environmentally friendly crop protection and nutrition: the PROTECTOR project. Woodhead Publishing Series in Food Science, Technology and Nutrition, Handbook of Waste Management and Co-Product Recovery in Food Processing 2009; 2:553-582.

[7] DeWalt, K., M. and DeWalt, B. R. DeWalt. Participant Observation: A Guide for Fieldworkers. Lanham, Maryland: Altamira Press. 2011.

[8] Vardhan P. V., Shukla S, Saxena J, Salman K, and Kumar R. Ginger (Zingiber Officinale Rosc.) Productivity in Tree Based Agro Forestry System. JOJ Hortic Arboric 2018; 1(4): 555-568

[9] Holmgren, D. Permaculture: principles \& pathways beyond sustainability. Hepburn: Holmgren Design Services. 2004.

[10] McGrath, C., Wright, D., Mallarino, A. P. and Lenssen, A. W. Soybean Nutrient Needs. Iowa State University: Agriculture and Environment Extension Publications. 2013. 
Indonesian Scholars Scientific Summit Taiwan Proceeding 2021

e-ISSN: 2797-2437

[11] Hill, D. S. Pests of Stored Foodstuffs and Their Control. Now york: Kluwer Academic Publisher, 2002.

[12] Salleh, A. M., Rosli, A. M. and Ibrahim, M. H. 2018. Permaculture Design: Linking Local Knowledge in Land Use Planning for House Compound. SHS Web of Conferences, 45, 03003. 